\title{
Influence of pitfall trap size and design on herpetofauna and small mammal studies in a Neotropical Forest
}

\author{
Marco A. Ribeiro-Júnior ${ }^{1,3}$; Rogério V. Rossi2; \\ Cleuton L. Miranda ${ }^{1} \&$ Teresa C. S. Ávila-Pires ${ }^{1}$
}

\author{
${ }^{1}$ Museu Paraense Emílio Goeldi \& Programa de Pós-graduação em Zoologia, Universidade Federal do Pará-Museu Paraense \\ Emílio Goeldi. Caixa Postal 399, 66017-970 Belém, Pará, Brazil. \\ ${ }^{2}$ Departamento de Biologia e Zoologia, Instituto de Biociências, Universidade Federal de Mato Grosso. 78060-900 Cuiabá, \\ Mato Grosso, Brazil. \\ ${ }^{3}$ Correspondig author. E-mail: majunior@museu-goeldi.br
}

\begin{abstract}
One of the most commonly used sampling techniques to capture leaf litter amphibians, lizards and small mammals is a set of pitfall traps with drift fences. However, there are still many speculations concerning the effectiveness of different designs of pitfall traps and the most adequate size of each trap. To address this problem, we conducted the first standardized comparison of patterns of species richness, rank-abundance, and community structure of leaf litter amphibians, lizards and small mammals for two trap designs ( $\mathrm{I}$ and $\mathrm{Y}$ format) and three bucket sizes $(35,62$, and $100 \mathrm{~L}$ ) in a Neotropical forest. Results are very similar for the herpetofauna, regardless of the pitfall trap design or size used, while for small mammals values of species richness were higher for $100 \mathrm{~L}$ pitfall traps, as compared to the smaller traps. Therefore, the use of $100 \mathrm{~L}$ pitfall traps is recommended to sample the terrestrial vertebrate fauna, in multidisciplinary studies. For surveys aiming only the herpetofauna the use of smaller $(35 \mathrm{~L})$ traps is acceptable, taking into consideration the cost-benefits obtained by the smaller traps, in comparison to the larger ones.
\end{abstract}

KEY WORDS. Amphibians; faunal survey; Neotropical forest; reptiles; sampling method; small mammals.

In biodiversity studies the choice of sampling methods is important in determining how well one is able to effectively sample the target fauna, and therefore how successfully the whole study is accomplished. Moreover, biodiversity studies will be of far more value if their results are comparable between sites, so that broader conclusions can be made - an important point for achieving a better understanding of the ecosystems and for the development of environmental policies. Such comparability however is difficult to achieve, especially in the absence of studies comparing the effectiveness of different designs of sampling methods, making their choice a question of personal preference. For terrestrial vertebrates, which concern many secretive species of leaf litter amphibians, lizards and small mammals, one of the most commonly used sampling technique are pitfall traps (THомpson et al. 2005), usually associated with drift fences to enhance their effectiveness (RICE et al. 1994). This method is effective for detection of rare species and estimation of species richness and abundance in small mammal and herpetofauna communities, even though restricted to leaf litter fauna (BuRY \& Raphael 1983, Bury \& Corn 1987, Greenberg et al. 1994, Rice et al. 1994, Ryan et al. 2002, Umetsu et al. 2006). Umetsu et al. (2006) suggested the technique as essential for inventorying the small mammal fauna of the tropics, capturing more species and more individuals than Sherman traps (but see SANTOS-FILHO et al. 2006 for opposite results). In a comparison between four herpetofaunal sampling techniques (pitfall, funnel and glue traps, and active sampling), Ribeiro-Júnior et al. (2008) found that pitfall traps captured the largest number of species in Amazonian primary forest, and the highest rate of exclusive leaf litter species. However, pitfall traps vary in many ways, which make it difficult to compare results from different studies. Besides, few studies compare the effectiveness of different designs and sizes of pitfall traps, both for herpetofauna and small mammals, and they are mostly confined to the Neartic region (e.g. MENGAK \& GuYNn 1978, ENGE 2001), Australian region (e.g. Hopper 1981, MenKhorst 1982, Braithwaite 1983, Friend \& Mitchell 1988, Morton et al. 1988, Friend et al. 1989, HobBs et al. 1994, Rolfe \& McKenzie 2000, Moseby \& Read 2001, Thompson et al. 2005), and Africa (e.g. Maritz et al. 2007). For the Neotropical region no study is available for small mammals. CECHIN \& MarTins (2000) made a descriptive comparison between previous herpetofaunal studies chosen from different biomes in Brazil, and RIBEIRO-JúNIOR et al. (2008) conducted a standardized comparison of patterns of species richness, rank-abundance, and community structure as revealed by two pitfall trap sizes (35 and $62 \mathrm{~L}$ buckets) in Amazonian forest.

A variety of containers has been used as pitfall traps, including metal cans, PVC pipes and plastic buckets or cones of varying dimensions (How et al. 1984). Differences between con- 
tainers represent one of the variables that may explain distinct results obtained in comparisons between methods. For instance, FRIEND et al. (1989) observed, in a study site in Australia, that small mammals were caught equally often in 20L buckets and 160 mm-diameter PVC pipes, while THOMPson et al. (2005) found that $150 \times 600 \mathrm{~mm}$ pipes caught more small mammals and the largest of small trappable mammals compared to $20 \mathrm{~L}$ buckets. The latter authors recommended a combination of $20 \mathrm{~L}$ buckets and $150 \mathrm{~mm}$-diameter pipes for sampling small mammals, considering that the use of only one pitfall type would produce a biased appreciation of the assemblage being trapped. For the herpetofauna, CECHIN \& MARTins (2000), comparing previous studies conducted in different biomes in Brazil, concluded that 100L-200L pitfalls were more efficient than 20-30 L pitfalls. However, Ribeiro-JúnIor et al. (2008) observed no differences between species richness, capture success, or community structure for lizards and leaf litter amphibians registered by pitfalls with 35 and 62 L buckets. Morton et al. (1988) showed that $290 \mathrm{~mm}$-diameter pitfalls are more efficient than $150 \mathrm{~mm}$-diameter pipes for capturing reptiles, as observed by Friend et al. (1989). Maritz et al. (2007) found no differences between species richness and capture success registered by pitfall traps with relatively small containers, 5 and $10 \mathrm{~L}$.

Regarding trap design, MoRTon et al. (1988) suggested the use of cross form as an optimal pitfall trap system to sample reptiles in spinifex grasslands in Australia, when compared to straight line design, but Новвs et al. (1994) tested several pitfall trap designs and concluded that differences in results were small, so that the simplest straight line design would be preferable.

In view of these contradictory results and the paucity of studies with focus on the Neotropical region, the effectiveness of two pitfall trap designs (straight line format - I; and Y format), and three pitfall trap sizes (35, 62, and $100 \mathrm{~L}$ buckets) are evaluated in a rainforest area in eastern Amazonia. In particular, these pitfall trap types are compared in relation to their performance with respect to patterns of species richness, relative abundance and community structure for leaf litter amphibians, reptiles and small mammals.

\section{MATERIAL AND METHODS}

This study was conducted in the 2,500 ha site of the Amazonia Biodiversity Research Program/PPBio-Amazônia, in Floresta Nacional de Caxiuanã (1 $\left.1^{\circ} 57^{\prime} 36^{\prime \prime} \mathrm{S}, 51^{\circ} 36^{\prime} 55^{\prime \prime} \mathrm{W}\right)$, an area of 330,000 ha in the Tocantins-Xingu interfluvium, state of Pará, Brazilian Amazonia, reserved for sustainable use (Fig. 1). About $85 \%$ of the area is terra firme rain forest, a well-drained forest not subject to seasonal inundation (ALmeIDA et al. 1993). The remaining area is igapó (flooded forest). The forest is characterized by a 30-35 m-tall closed canopy, with emergents growing to $45 \mathrm{~m}$ (Amaral et al. 2009). The climate is of the Am type in the classification of Köppen, with mean annual rainfall between 1996 and 2003 of 1960 mm, divided into a rainy sea-

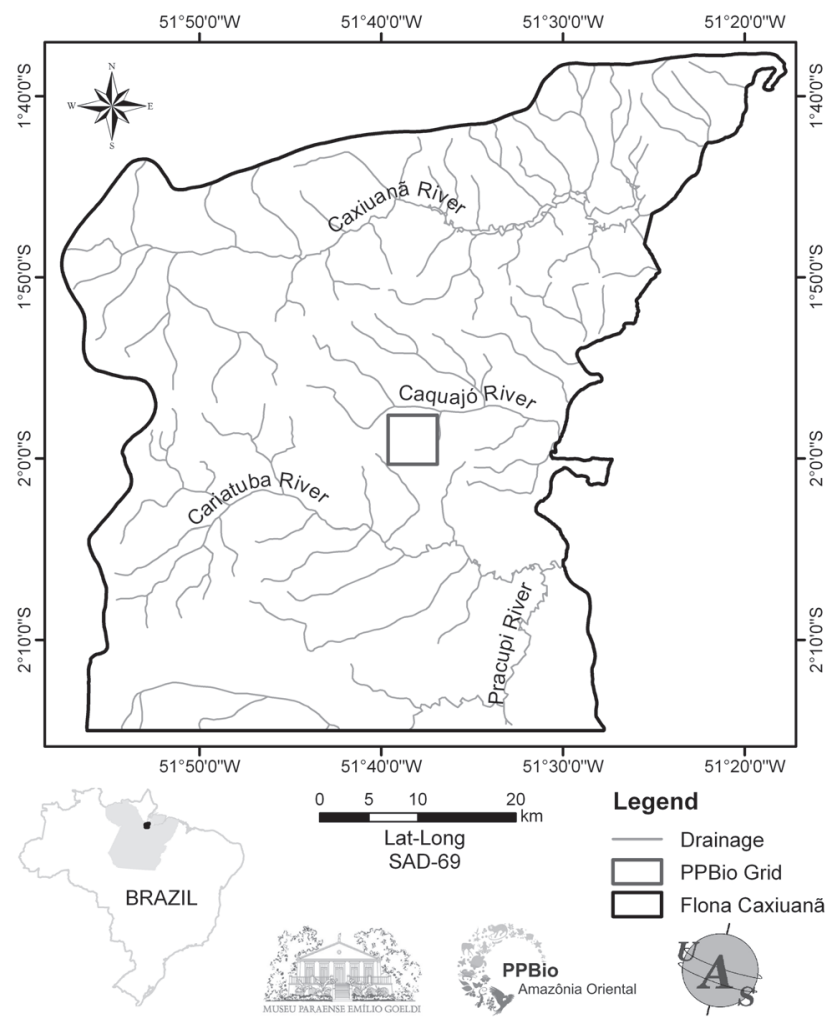

Figure 1. Location of the PPBio research site in the Floresta Nacional (Flona) de Caxiuanã, state of Pará, Brazilian Amazonia.

son, from December to May, and a dry season, from June to November; mean annual temperature between 1996 and 2003 of $26.7^{\circ} \mathrm{C}$ (Costa et al. 2009).

Leaf litter amphibians, lizards, snakes, and non-volant small mammals were sampled at the PPBio site between January and November 2007. Eighteen pitfall trap arrays were used, six of which with 35 L buckets, six with 62 L buckets, and six with $100 \mathrm{~L}$ buckets. The $35 \mathrm{~L}$ buckets were $450 \mathrm{~mm}$ deep, with an upper diameter of $350 \mathrm{~mm}$ and a lower diameter of 250 $\mathrm{mm}$; the $62 \mathrm{~L}$ buckets were $570 \mathrm{~mm}$ deep, with upper and lower diameters of 410 and $310 \mathrm{~mm}$; and the $100 \mathrm{~L}$ buckets were 820 $\mathrm{mm}$ deep, with an upper diameter of $520 \mathrm{~mm}$ and a lower diameter of $390 \mathrm{~mm}$, respectively. Nine pitfall arrays were Y-shaped (one central bucket linked to three peripheral ones, the three arms forming angles of approximately $120^{\circ}$ ), and nine I-shaped (four buckets in a straight line). Therefore, for each shape (Y or I), there were three pitfall arrays with $35 \mathrm{~L}$ buckets, three with $62 \mathrm{~L}$ buckets, and three with $100 \mathrm{~L}$ buckets. Buckets belonging to the same pitfall array were connected by a $10 \mathrm{~m}$ long and $80 \mathrm{~cm}$-high plastic drift fence. Pitfall arrays were set $150 \mathrm{~m}$ from one another along a transect, in order to provide spatially independent sample units. Pitfall transects were par- 
allel to, but at least $50 \mathrm{~m}$ distant from, the walking trails. The different types of pitfall arrays were arranged alternately, considering bucket size and trap design types, in two transects distant $1 \mathrm{~km}$ from each other.

Each pitfall array was sampled for a total of 15 consecutive days in January-February, 17 consecutive days in March-April, 18 consecutive days in June-July, and 17 consecutive days in November. Sampling effort across all sample units totaled 1,206 pitfall-trap array nights, shared equally between the three bucket sizes (402 array nights for $35 \mathrm{~L}$ pitfall trap, 62 $\mathrm{L}$ pitfall trap, and $100 \mathrm{~L}$ pitfall trap), and trap design (630 Y pitfall trap array nights, and 630 I pitfall trap array nights). Traps were checked every morning by two observers. Each amphibian, reptile and small mammal captured was identified and measured; all specimens were collected and deposited as vouchers in Museu Paraense Emílio Goeldi, Belém, Brazil (cata$\log$ numbers available on request from the authors).

Analyses were conducted separately for leaf litter amphibians, lizards, and small mammals. Differences in species richness obtained by the different types of pitfall arrays were analyzed using individual based rarefaction (Gotelur \& Colwell 2001), and sample based rarefaction pooling data from all samples of each pitfall type (Thompson et al. 2003, Thompson et al. 2005). Rarefaction analyses were implemented in EstimateS v. 7.0 (Colwell 2004). Perceived species richness were considered significantly different whenever the lower 95\% confidence interval of the curve with highest values did not overlap with the remaining mean curves (MAGURRAN 2004). To compare species-abundance patterns obtained by each sampling method, we used standardized Whittaker plots, which compare species rank with log of relative abundance (MAGURRAN 2004). In addition, abundance ranks were compared between methods using nonparametric Spearman-rank correlations. All statistical tests were carried out using SPSS v.11.5 (SPSS 2001).

To evaluate differences in perceived patterns of community structure, as revealed by different sampling techniques, we used Nonmetric Multidimensional Scaling (NMDS). NMDS was prefered over other ordination techniques because this method does not impose limiting assumptions concerning the nature of species responses (CLARKE \& WarWick 2001, MCCunE \& Grace 2002). Similarity matrices for each method were based on Bray-Curtis similarity index using square-root transformed and site standardized abundance data. Analysis of Similarity (ANOSIM, CLARKE \& WARWICK 2001) was used to compare differences in community structure between pitfall trap types (bucket size and trap design). All multivariate analyses were conducted using Primer v. 5 (Clarke \& Warwick 2001).

The snout-vent length (SVL) for herpetofauna and headbody length (HBL) for small mammals were measured to obtain the average length of individuals collected by each trap type, and was then compared using parametric one-way ANOVA to examine whether pitfall trap size and design differed in their selection of body size (correcting for unequal variances when necessary). Pairwise post hoc comparisons were made using Tukey's subsets between each trap type with different size buckets. Maximum and minimum SVL or HBL of the individuals captured per pitfall trap type were compared to estimate variation in body size registered by each method for different species groups.

\section{RESULTS}

A total of 1,240 individuals was captured (Tab. I), comprising 21 leaf litter amphibian species (807 individuals), 17 lizard species (234 individuals), 10 snake species (12 individuals), and 13 small mammal species (187 individuals). Snakes were not included in the analyses because of insufficient captures.

Rarefaction analyses showed that there was no significant difference between the number of leaf litter amphibian and lizard species captured with 35, 62, and 100 L buckets (Figs 2 and $3)$. For small mammals, similar species richness was observed for 35 and $62 \mathrm{~L}$ pitfall traps, but more species were captured by $100 \mathrm{~L}$ pitfall traps (Fig. 4). When comparing trap design, number of species recorded by I and Y design was not significantly different in any of the three groups (Figs 2-4). Results were similar for both individual based rarefaction and sample based rarefaction, for all groups analyzed. Species recorded by less than three individuals were not included in species richness analyses (four amphibian species, five lizards, and three small mammals; Tab. I). It is considered that they may be rare/uncommon in the study area and the low number of captures are not due to any kind of trap selection. Among them, five (three amphibians: Colostethus sp. - I design, Leptodactylus petersii (Steindachner, 1864) - Y design, Chiasmocleis jimi Caramaschi \& Cruz, 2001 - I and Y design; and two lizards: Anolis ortonii Cope, 1869, Mabuya nigropunctata Andersson, 1918 - both in I design) were only captured in $100 \mathrm{~L}$ pitfalls; one lizard species (Bachia flavescens (Bonaterre, 1789) - Y design) was only captured in a $62 \mathrm{~L}$ trap array; and three species (two lizards: Iphisa elegans Gray, 1851 I design, Anolis punctatus Daudin, 1802 - Y design; and one small mammal: Oecomys bicolor (Tomes, 1860) - I design) were only captured in 35L pitfalls. Although $100 \mathrm{~L}$ pitfalls captured more small mammal species than pitfalls with smaller bucket sizes, they failed to register Oecomys bicolor, represented by a single specimen captured by a 35L pitfall (Tab. I). Among species represented by four or more specimens (included in the species richness analyses), only one lizard, Anolis fuscoauratus Duméril \& Bibron, 1837, was exclusive to $62 \mathrm{~L}$ pitfalls, and a few others (the amphibians Adenomera sp. 2 and Physalaemus ephippifer (Steindachner, 1864), the lizard Plica umbra (Linnaeus, 1758), and the mammals Didelphis marsupialis Linnaeus, 1758 and Makalata didelphoides (Desmarest, 1817)) were not captured by one of the bucket sizes. Considering trap design, the amphibian Leptodactylus rhodomystax Boulenger, 1884 was sampled only by I-shaped traps, while Y-shaped traps did not register any exclusive species (Tab. I). 
Table I. Species and number of individuals of leaf litter amphibians, lizards, snakes and small mammals captured by different pitfall trap types in the PPBio research site of the Floresta Nacional de Caxiuanã, Brazilian Amazon. (I) Pitfall traps with line design, (Y) pitfall traps with $\mathrm{Y}$ design, (ANS) abbreviation of species names used in figures 5 and 6.

\begin{tabular}{|c|c|c|c|c|c|c|c|c|}
\hline \multirow{2}{*}{ ANS } & \multirow{2}{*}{ Species } & \multicolumn{2}{|c|}{$35 \mathrm{~L}$ pitfalls } & \multicolumn{2}{|c|}{$62 \mathrm{~L}$ pitfalls } & \multicolumn{2}{|c|}{$100 \mathrm{~L}$ pitfalls } & \multirow{2}{*}{ Total } \\
\hline & & I & Y & 1 & Y & I & $\mathrm{Y}$ & \\
\hline \multicolumn{9}{|c|}{ Amphibians } \\
\hline B & Bufo cf. magnussoni & 41 & 28 & 36 & 27 & 49 & 40 & 221 \\
\hline $\mathrm{Db}$ & Dendrophryniscus bokermanni & 28 & 3 & 7 & 14 & 13 & 12 & 77 \\
\hline Af & Allobates femoralis & 4 & 2 & 5 & 2 & 8 & & 21 \\
\hline $\mathrm{C}$ & Colostethus sp. & & & & & 2 & & 2 \\
\hline $\mathrm{Dg}$ & Dendrobates galactonotus & & 5 & & 2 & 1 & 2 & 10 \\
\hline Dv & Dendrobates ventrimaculatus & 1 & 1 & & & 1 & & 3 \\
\hline $\mathrm{A} 1$ & Adenomera sp. 1 & 8 & 3 & 35 & 23 & 12 & 12 & 93 \\
\hline A2 & Adenomera sp. 2 & & & 2 & 2 & 3 & & 7 \\
\hline $\mathrm{Cc}$ & Ceratophrys cornuta & 4 & & 7 & 1 & 20 & 1 & 33 \\
\hline Ef & Eleutherodactylus fenestratus & 1 & 2 & 2 & & 2 & & 7 \\
\hline Lk & Leptodactylus knudseni & & & & 1 & 1 & & 2 \\
\hline $\mathrm{Lm}$ & Leptodactylus mystaceus & 3 & 1 & 7 & 10 & 23 & 9 & 53 \\
\hline Lp & Leptodactylus paraensis & 3 & 5 & 7 & 5 & 19 & 20 & 59 \\
\hline Lpe & Leptodactylus pentadactylus & & 1 & 2 & 1 & 4 & 2 & 10 \\
\hline Lpt & Leptodactylus petersii & & & & & & 1 & 1 \\
\hline $\mathrm{Lr}$ & Leptodactylus rhodomystax & 1 & & 3 & & 5 & & 9 \\
\hline $\mathrm{Pe}$ & Physalaemus ephippifer & & & 1 & 3 & 14 & 1 & 19 \\
\hline $\mathrm{Ca}$ & Chiasmocleis avilapiresae & 1 & 2 & 1 & 3 & 21 & & 28 \\
\hline $\mathrm{Cj}$ & Chiasmocleis jimi & & & & & 1 & 1 & 2 \\
\hline $\mathrm{Cg}$ & Ctenophryne geayi & 7 & 4 & 7 & 4 & 15 & 5 & 42 \\
\hline \multirow[t]{3}{*}{$\mathrm{Hb}$} & Hamptophryne boliviana & 9 & 5 & 13 & 6 & 72 & 3 & 108 \\
\hline & tal amphibians & 111 & 62 & 135 & 104 & 286 & 109 & 807 \\
\hline & ards & & & & & & & \\
\hline $\mathrm{Ca}$ & Coleodactylus amazonicus & 4 & 6 & 11 & 12 & 13 & 8 & 54 \\
\hline Gh & Gonatodes humeralis & & 2 & 1 & 1 & 8 & 3 & 15 \\
\hline $\operatorname{Ar}$ & Arthrosaura reticulata & 7 & 6 & 11 & 9 & 13 & 9 & 55 \\
\hline $\mathrm{Bf}$ & Bachia flavescens & & & & 2 & & & 2 \\
\hline $\mathrm{Co}$ & Cercosaura ocellata & 3 & 2 & 1 & & 4 & 1 & 11 \\
\hline le & Iphisa elegans & 1 & & & & & & 1 \\
\hline Lp & Leposoma percarinatum & 2 & & 2 & 1 & 2 & 1 & 8 \\
\hline $\mathrm{Pb}$ & Ptychoglossus brevifrontalis & 2 & 1 & 4 & & 3 & 1 & 11 \\
\hline $\mathrm{Ta}$ & Tretioscincus agilis & 4 & 5 & 5 & 1 & & 5 & 20 \\
\hline Af & Anolis fuscoauratus & & & 2 & 2 & & & 4 \\
\hline Ao & Anolis ortonii & & & & & 1 & & 1 \\
\hline Ap & Anolis punctatus & & 1 & & & & & 1 \\
\hline $\mathrm{Pp}$ & Plica plica & & 1 & & 2 & 1 & & 4 \\
\hline
\end{tabular}


Table I. Continued.

\begin{tabular}{|c|c|c|c|c|c|c|c|c|}
\hline \multirow{2}{*}{ ANS } & \multirow{2}{*}{ Species } & \multicolumn{2}{|c|}{$35 \mathrm{~L}$ pitfalls } & \multicolumn{2}{|c|}{$62 \mathrm{~L}$ pitfalls } & \multicolumn{2}{|c|}{$100 \mathrm{~L}$ pitfalls } & \multirow{2}{*}{ Total } \\
\hline & & 1 & $\mathrm{Y}$ & 1 & $\mathrm{Y}$ & 1 & $\mathrm{Y}$ & \\
\hline $\mathrm{Pu}$ & Plica umbra & & 1 & & & 3 & & 4 \\
\hline $\mathrm{Mn}$ & Mabuya nigropunctata & & & & & 1 & & 1 \\
\hline $\mathrm{Aa}$ & Ameiva ameiva & & 1 & & 4 & 1 & 1 & 7 \\
\hline \multirow[t]{15}{*}{$\mathrm{Kc}$} & Kentropyx calcarata & & 5 & 4 & 6 & 11 & 9 & 35 \\
\hline & Total lizards & 23 & 31 & 41 & 40 & 61 & 38 & 234 \\
\hline & Snakes & & & & & & & \\
\hline & Atractus schach & 1 & & & & & & 1 \\
\hline & Atractus snethlageae & & & 1 & & & 1 & 2 \\
\hline & Erythrolamprus aesculapii & & & & & & 1 & 1 \\
\hline & Leptodeira annulata & 1 & & & & & & 1 \\
\hline & Oxyrhopus melanogenys & & & & & 1 & & 1 \\
\hline & Taeniophallus brevirostris & & & & & & 1 & 1 \\
\hline & Taeniophallus occipitalis & & & 1 & & & & 1 \\
\hline & Xenopholis scalaris & & & & 1 & & & 1 \\
\hline & Micrurus lemniscatus & & & 1 & 1 & & & 2 \\
\hline & Micrurus paraensis & & & & 1 & & & 1 \\
\hline & Total snakes & 2 & 0 & 3 & 3 & 1 & 3 & 12 \\
\hline & Small mammals & & & & & & & \\
\hline $\mathrm{Dm}$ & Didelphis marsupialis & & & 1 & 2 & & 2 & 5 \\
\hline $\mathrm{Mp}$ & Marmosops cf. pinheiroi & 7 & 7 & 4 & 5 & 5 & 7 & 35 \\
\hline $\mathrm{Mr}$ & Metachirus nudicaudatus & 1 & & 1 & & 2 & 1 & 5 \\
\hline Mde & Micoureus demerarae & & 1 & 1 & & & & 2 \\
\hline $\mathrm{Mb}$ & Monodelphis brevicaudata & 4 & 1 & 5 & 2 & 6 & 6 & 24 \\
\hline $\mathrm{Em}$ & Euryoryzomys macconnelli & 4 & 3 & 9 & 3 & 15 & 3 & 37 \\
\hline $\mathrm{Nm}$ & Nectomys melanius & & & & 1 & 2 & & 3 \\
\hline $\mathrm{Ob}$ & Oecomys bicolor & 1 & & & & & & 1 \\
\hline $\mathrm{Oa}$ & Oecomys auyantepui & 3 & 5 & 6 & 12 & 8 & 10 & 44 \\
\hline $\mathrm{R}$ & Rhipidomys sp. & & & 1 & & 1 & & 2 \\
\hline $\mathrm{Md}$ & Makalata didelphoides & 1 & 1 & & & 3 & & 5 \\
\hline Ms & Mesomys stimulax & & 1 & 1 & 3 & 5 & 1 & 11 \\
\hline$P$ & Proechimys sp. & & 1 & 3 & 1 & 5 & 3 & 13 \\
\hline & Total small mammals & 21 & 20 & 32 & 29 & 52 & 33 & 187 \\
\hline
\end{tabular}

Both pitfall designs presented an even species-relative abundance distribution for leaf litter amphibians, lizards and small mammals (Figs 5 and 6). For leaf litter amphibians, of the five most abundant species, four were the same in I and Y designs (Bufo cf. magnussoni Lima, Menin \& Araújo, 2007, Adenomera sp. 1, Dendrophryniscus bokermanni Izechsohn, 1994, and Leptodactylus mystaceus (Spix, 1824)), representing 49.2\% and $66.4 \%$ of all captures respectively (Fig. 5). Bufo cf. magnussoni was the most frequently sampled species, both by I design (23.7\% of all records) and Y design (34.7\% of all records). For lizards (Fig. 5), the three most abundant species represented $60 \%$ of all lizards captured by I design and $64 \%$ by Y design. In both designs, Arthrosaura reticulata (O'Shaughnessy, 1881) and Coleodactylus amazonicus (Andersson, 1918) were the most abun- 

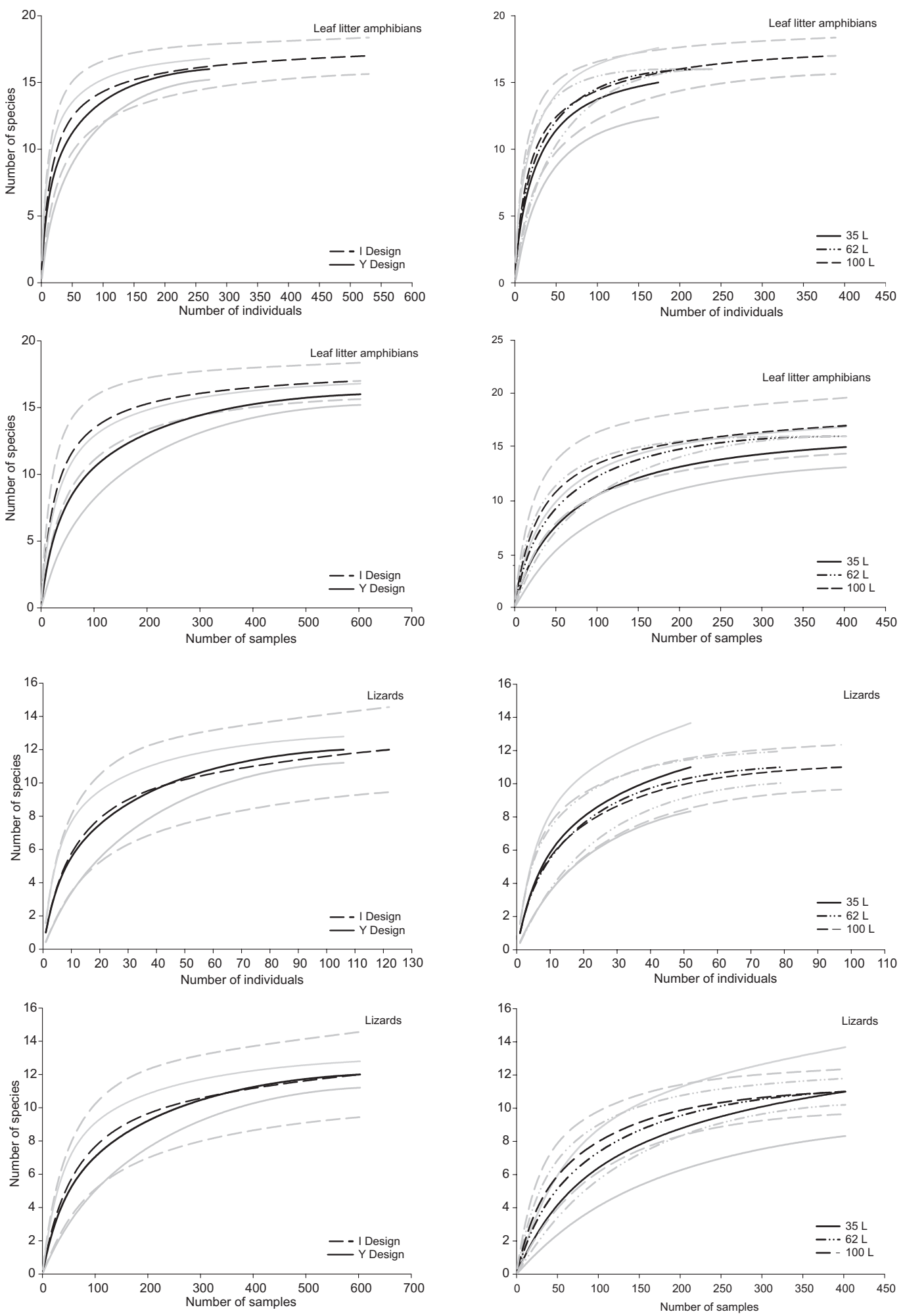

3

Figures 2-3. Individual based rarefaction curves and sample based rarefaction curves for (2) leaf litter amphibians and (3) lizards captured by I and Y pitfall trap designs, and 35, 62 and $100 \mathrm{~L}$ pitfall traps sizes. Gray lines represent 95\% confidence intervals. 

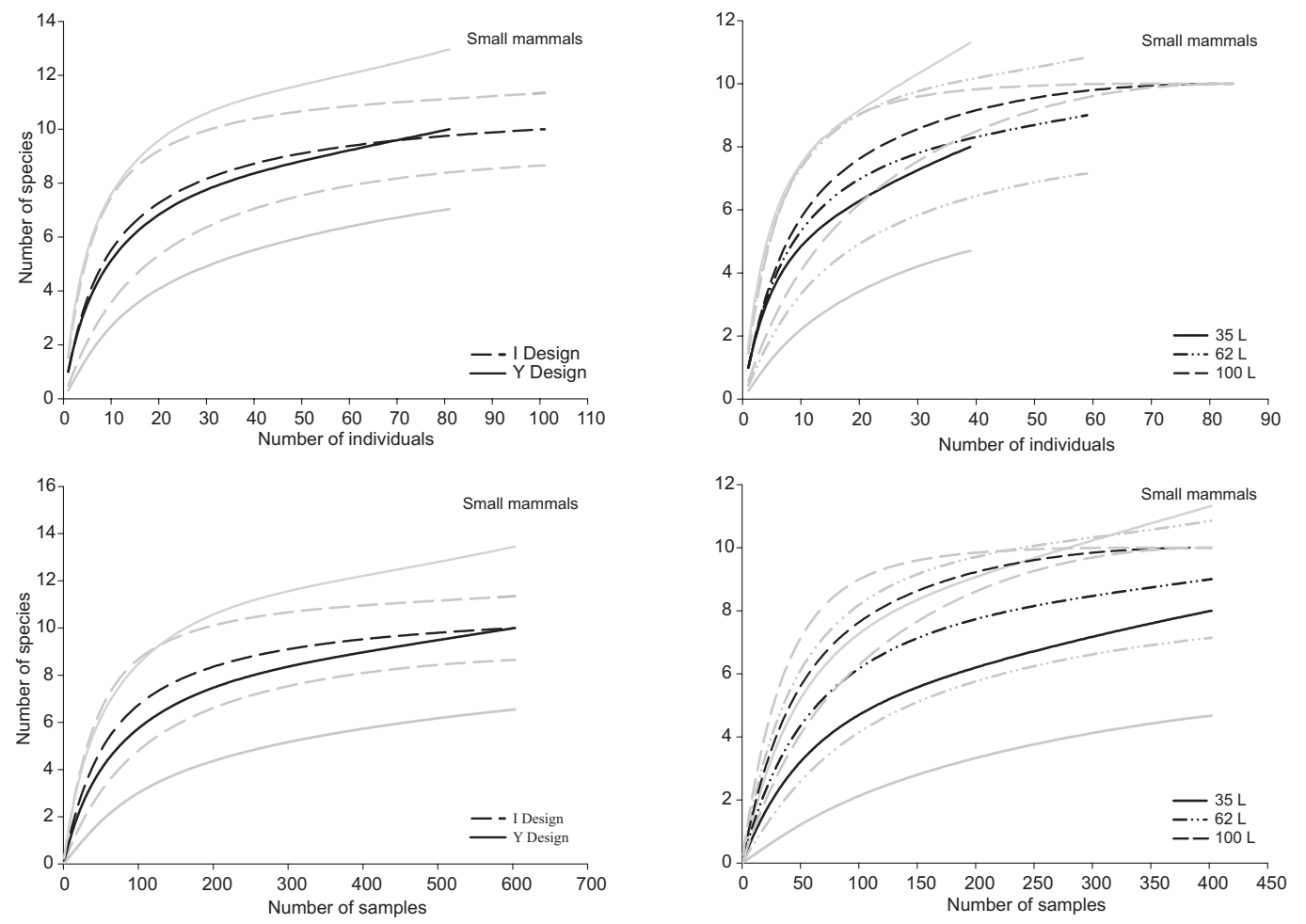

Figure 4. Individual based rarefaction curves and sample based rarefaction curves for small mammals captured by I and $\mathrm{Y}$ pitfall trap designs, and 35, 62 and $100 \mathrm{~L}$ pitfall traps sizes. Gray lines represent 95\% confidence intervals.

dant species (I design $-24.8 \%$ and $22.4 \%$ respectively; Y design $-22 \%$ and $23.9 \%$, respectively). For small mammals (Fig. 5), the four most abundant species were the same for both designs (Euryoryzomys macconnelli (Thomas, 1910) - 26.7\% in I design and $11 \%$ in Y design; Oecomys auyantepui Tate, 1939 $16.2 \%$ in I design, and $32.9 \%$ in Y design; Marmosops cf. pinheiroi Pine, 1981 - $15.2 \%$ in I design and $23.1 \%$ in Y design; Monodelphis brevicaudata (Erxleben, 1777) - 14.3\% in I design and $11 \%$ in Y design).

Regarding pitfalls with different bucket sizes, for leaf litter amphibians, 35L pitfalls registered two dominant species (B. cf. magnussoni and D. bokermanni - $40 \%$ and $18 \%$ respectively), comprising together $58 \%$ of all captures by this bucket size. The same capture rate was observed for the five most abundant species captured by 62L pitfalls (B. cf. magnussoni, Adenomera sp. 1, D. bokermanni, Hamptophryne boliviana (Parker, 1927) and L. mystaceus - all together 57.2\%) and the four most abundant species in $100 \mathrm{~L}$ pitfalls (B. cf. magnussoni, H. boliviana, Leptodactylus paraensis Heyer, 2005, and L. mystaceus - all together 59.5\%), indicating that 62 and $100 \mathrm{~L}$ pitfalls present more even species-abundant curves than 35 L pitfalls (Fig. 6). For lizards, the three bucket sizes presented relatively even species-abundance curves (Fig. 6), with the four most abundant species representing $68.5 \%, 72.8 \%$ and $59 \%$ of all species cap- tured by 35, 62 and $100 \mathrm{~L}$ pitfalls, respectively. The two most abundant species (A. reticulata and C. amazonicus) were the same for all three bucket sizes. For small mammals (Fig. 6), the three most abundant species captured by 35, 62, and $100 \mathrm{~L}$ pitfalls were the same, although the most abundant species in $35 \mathrm{~L}$ pitfalls (M. cf. pinheiroi), represented by $34.1 \%$ of all captures, was only the third most abundant in 62 and $100 \mathrm{~L}$ pitfalls ( $14.75 \%$ and $14.1 \%$ respectively). Oecomys auyantepui was the most abundant species registered by $62 \mathrm{~L}$ pitfalls $(29.5 \%$ of all individuals captured), while both $O$. auyantepui and $E$. macconnelli were the most abundant species in $100 \mathrm{~L}$ pitfalls (each representing $21.2 \%$ of all captures). Pitfalls of $100 \mathrm{~L}$ buckets presented the most even species-abundance curve, those of $35 \mathrm{~L}$ buckets the most uneven species-abundance distribution.

Rank orders of abundance of individual species trapped by I-shaped and Y-shaped pitfalls were not significantly different for leaf litter amphibians (21 species, rs $=0.777, \mathrm{p}<0.001$ ), lizards (17 species, $\mathrm{rs}=0.725, \mathrm{p}<0.001$ ) and small mammals (14 species, $r s=0.749, \mathrm{p}=0.002$ ). Rank orders of abundance obtained from traps with different bucket sizes were also not significantly different for leaf litter amphibians (35 and $62 \mathrm{~L}$ pitfalls $-\mathrm{rs}=0.827, \mathrm{p}<0.001 ; 62$ and $100 \mathrm{~L}$ pitfalls $-\mathrm{rs}=0.937$, $\mathrm{p}<0.001 ; 35$ and $100 \mathrm{~L}$ pitfalls $-\mathrm{rs}=0.790, \mathrm{p}<0.001$ ); lizards 

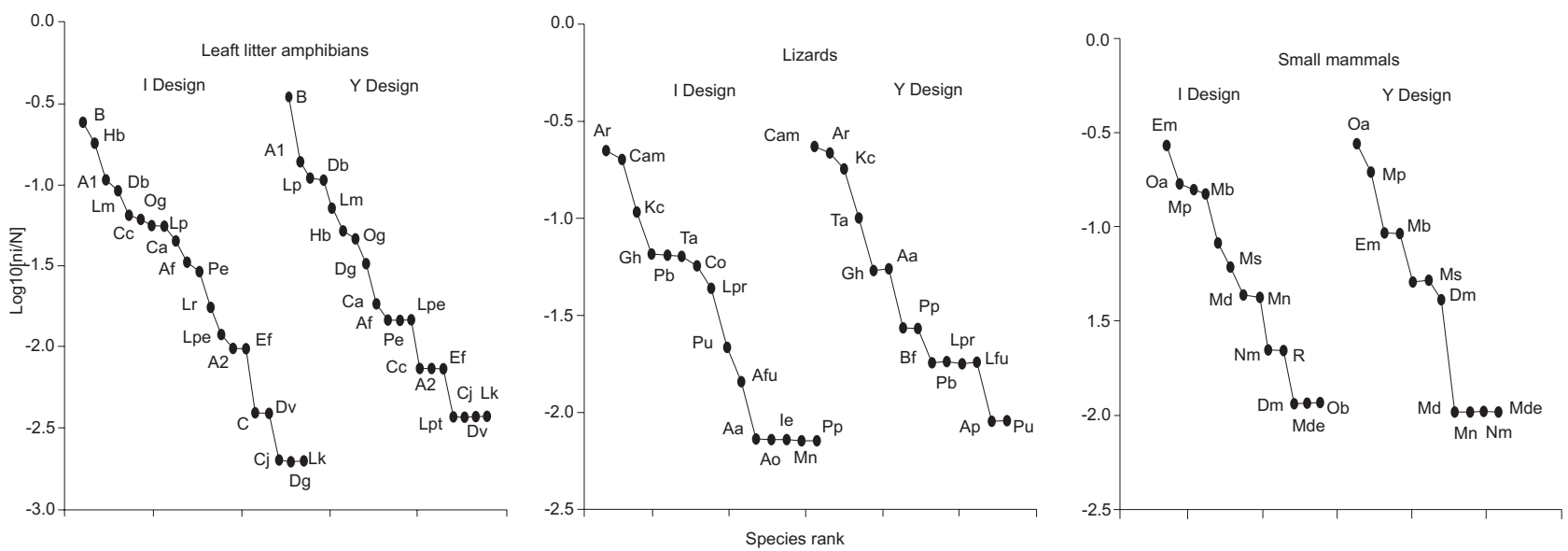

Figure 5. Leaf litter amphibian, lizard and nonvolant small mammal species rank-abundance curves (Whittaker plots) registered by the different pitfall trap design ( $\mathrm{I}$ and $\mathrm{Y}$ ). Abbreviation of species names are given on table I.
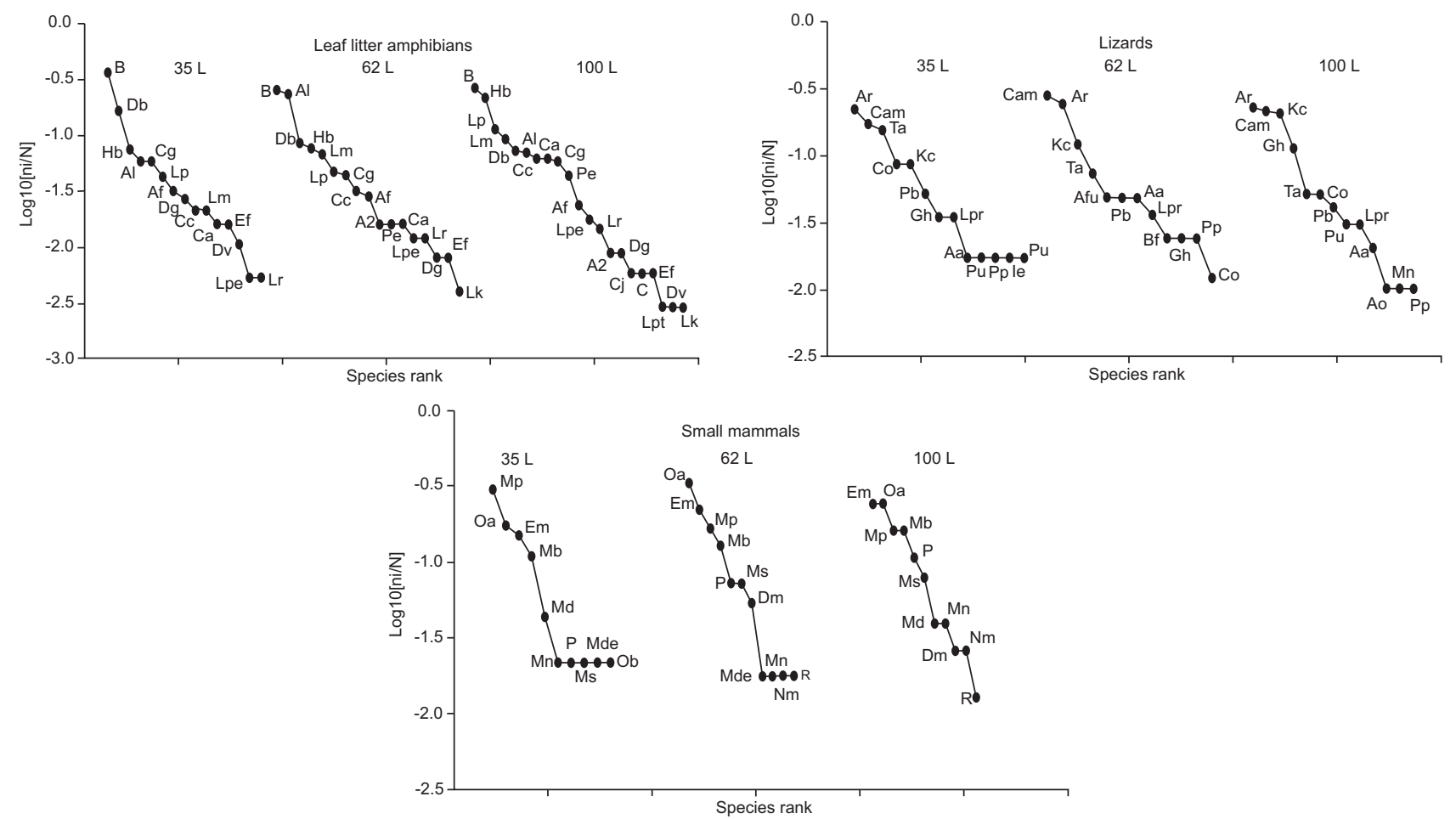

Figure 6. Leaf litter amphibian, lizard and nonvolant small mammal species rank-abundance curves (Whittaker plots) registered by 35 , 62 , and $100 \mathrm{~L}$ pitfall traps. Abbreviation of species names are given on table I.

(35 and $62 \mathrm{~L}-\mathrm{rs}=0.665, \mathrm{p}=0.004 ; 62$ and $100 \mathrm{~L}-\mathrm{rs}=0.641$, $\mathrm{p}=0.006 ; 35$ and $100 \mathrm{~L}-\mathrm{rs}=0.878, \mathrm{p}<0.001)$; and small mammals $(35$ and $62 \mathrm{~L}-\mathrm{rs}=0.575, \mathrm{p}=0.032 ; 62$ and $100 \mathrm{~L}-$ $\mathrm{rs}=0.836, \mathrm{p}<0.001 ; 35$ and $100 \mathrm{~L}-\mathrm{rs}=0.735, \mathrm{p}=0.002)$.

There were no significant differences in the observed pattern of leaf litter amphibian, lizard or small mammal community structure as revealed by each trap design (Fig. 7). In the case of different pitfall trap sizes, for all groups analyzed, there were no differences in the pattern revealed by the three sizes, as well as in pairwise comparisons between 35 and $62 \mathrm{~L}$ pitfalls, 62 and $100 \mathrm{~L}$, and 35 and $100 \mathrm{~L}$ pitfalls (Fig. 8). All statistic results of ANOSIM are presented in Figs. 7-8. 

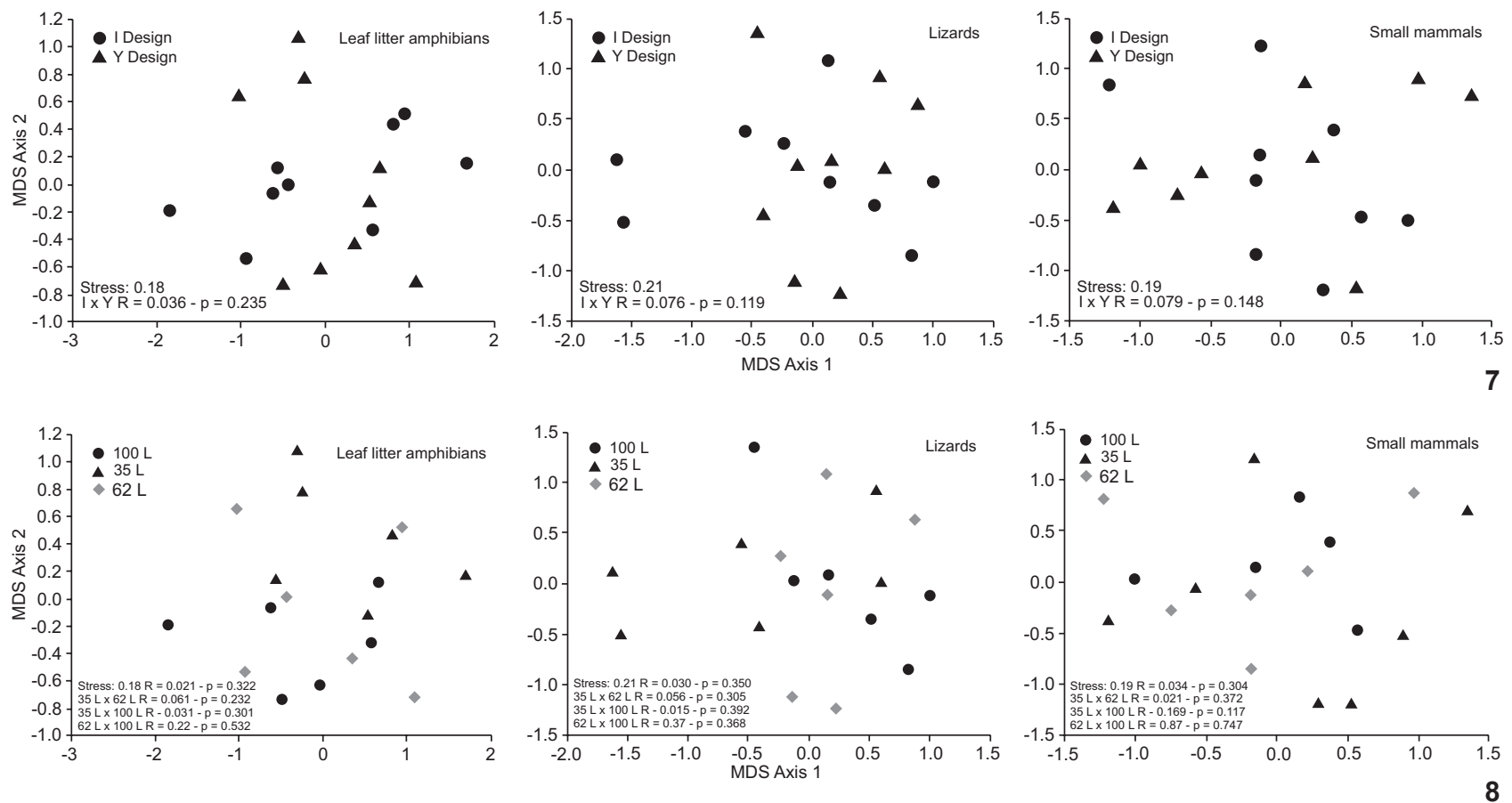

Figures 7-8. Nonmetric Multidimensional scaling plots produced from the Bray-Curtis similarity matrix of species abundance by different pitfall trap (7) designs ( $\mathrm{I}$ and $\mathrm{Y}$ ) and (8) sizes $(35,62$, and $100 \mathrm{~L})$ for leaf litter amphibians, lizards and small mammals. Clusters of similar symbols would indicate sampling bias of pitfall trap design.

Trap design showed no influence on the sizes of specimens sampled in any of the groups (ANOVA, leaf litter amphibians: $\mathrm{F}=0.304, \mathrm{df}=1,648, \mathrm{p}=0.582$; lizards: $\mathrm{F}=0.339$, $\mathrm{df}=1,173, \mathrm{p}=0.561$; small mammals: $\mathrm{F}=0.001, \mathrm{df}=1,185, \mathrm{p}$ $=0.969)$. Regarding bucket sizes, there was a significant difference between lengths of leaf litter amphibians registered by 35 , 62 , and $100 \mathrm{~L}$ pitfalls (ANOVA, $\mathrm{F}=4.123, \mathrm{df}=2,648, \mathrm{p}=0.017$ ). Pairwise comparisons showed a significant difference only between 62 and $100 \mathrm{~L}$ pitfalls, where $62 \mathrm{~L}$ pitfalls captured smaller specimens on average than 100 L pitfalls; 35 and 62, 35, and $100 \mathrm{~L}$ pitfalls captured similar-sized specimens (Tab. II). In terms of maximum size, $35 \mathrm{~L}$ pitfalls captured the largest leaf litter amphibian (L. paraensis, $158 \mathrm{~mm}$ ). For lizards, average length of specimens obtained by the three bucket sizes were not significantly different, either when all three were compared to each other (ANOVA, $\mathrm{F}=0.316$, $\mathrm{df}=2,173, \mathrm{p}=0.729$ ). The largest lizard was registered by $35 \mathrm{~L}$ pitfalls [Ameiva ameiva (Linnaeus, 1758), $182 \mathrm{~mm}$ ] and the smallest by $100 \mathrm{~L}$ pitfalls (C. amazonicus, $12 \mathrm{~mm}$; Tab. II). The same was obtained for small mammals (ANOVA, $\mathrm{F}=2.592, \mathrm{df}=2,185, \mathrm{p}=0.078$ ). Buckets of $62 \mathrm{~L}$ registered the largest mammal (D. marsupialis, $337 \mathrm{~mm}$ ), and $100 \mathrm{~L}$ the smallest (M. cf. pinheiroi, $65 \mathrm{~mm}$; Tab. II). For snakes, even though we did not catch enough specimens to conduct a formal analysis, our preliminary data indicate that $100 \mathrm{~L}$ buckets failed to catch larger animals than 35 and $62 \mathrm{~L}$ pitfall trap arrays.

\section{DISCUSSION}

Previous studies in the Floresta Nacional de Caxiuanã, including both active search and pitfall trap collecting, recorded 37 species of amphibians, 24 of lizards, and 70 of snakes (ÁvilaPires \& Hoogmoed 1997, Bernardi et al. 1999, Estupiñán et al. 2002, MASCHIO et al. 2009, and specimens from MPEG herpetological collection). The present study recorded 21 species of amphibians, 17 of lizards and 10 of snakes, all previously known from the Floresta Nacional de Caxiuanã, except for four amphibians that represent new records (Adenomera sp. 2, $P$. ephippifer, Ctenophryne geayi Mocquard, 1904, and C. jimi). Small mammals have not been previously surveyed in the area, but LAMBert et al. (2005) recorded 25 species in the Estação de Pesquisa Pinkaiti, within the Tocantins-Xingu interfluvium. In the present study 13 small mammal species were recorded. It should be noted, however, that only those species that occupy the leaf litter can be expected to be sampled by pitfall traps. Part of the difference in the numbers above, from all three groups, are due to species that do not occur in the leaf litter.

Our results agree with those by MоRTON et al. (1988) and Новвs et al. (1994) in that trap design (a straight line or with extra arms) has little effect on species sampled. Those studies focused on reptiles, but we got similar results for amphibians and small mammals. For all three groups the present study 
Table II. Comparison of snout-vent length (SVL, amphibians and lizards) and head-body length (HBL, mammals) captured by different trap sizes in each faunal group. First line corresponds to mean SVL or HBL \pm standard deviation. Second and third lines show "species (pitfall design) - SVL or HBL" of respectively the largest and smallest animal captured by each trap size. Fourth and fifth lines show the significance level of pairwise Tukey post hoc comparisons (P). All measurements are in millimeters. Species abbreviations: (Lp) Leptodactylus paraensis, (A1) Adenomera sp. 1, (Aa) A. ameiva, (Cam) C. amazonicus, (Mb) M. brevicaudata, (Dm) D. marsupialis, (Mp) M. cf. pinheiroi.

\begin{tabular}{|c|c|c|c|}
\hline \multirow{2}{*}{ Measurements } & $35 \mathrm{~L}$ pitfalls & $62 \mathrm{~L}$ pitfalls & $100 \mathrm{~L}$ pitfalls \\
\hline & \multicolumn{3}{|c|}{ Leaf litter amphibians } \\
\hline$S V L \pm S E$ & $41.3 \pm 1.3$ & $39.1 \pm 1.4$ & $47.4 \pm 1.3$ \\
\hline Maximum SVL & $\operatorname{Lp}(Y)-158$ & Lp (I) - 149 & Lp (I) - 149 \\
\hline Minimum SVL & A1 $(I-Y)-11$ & $A 1(Y)-9$ & A1 $(I-Y)-10$ \\
\hline $62 \mathrm{~L}$ pitfalls & $p=0.429$ & & \\
\hline \multirow[t]{2}{*}{$100 \mathrm{~L}$ pitfalls } & $p=0.415$ & $p=0.013^{*}$ & \\
\hline & \multicolumn{3}{|c|}{ Lizards } \\
\hline$S V L \pm S E$ & $50.9 \pm 4.2$ & $50.2 \pm 3.3$ & $54.3 \pm 3.2$ \\
\hline Maximum SVL & Aa $(I)-182$ & $\mathrm{Aa}(Y)-147$ & Aa $(Y)-177$ \\
\hline \multirow[t]{2}{*}{ Minimum SVL } & Cam (I) - 17 & $\operatorname{Cam}(Y)-14$ & Cam (I) -12 \\
\hline & \multicolumn{3}{|c|}{ Small mammals } \\
\hline $\mathrm{HBL} \pm \mathrm{SE}$ & $110.8 \pm 5.13$ & $130.1 \pm 6.9$ & $123.5 \pm 3.7$ \\
\hline Maximum HBL & $\mathrm{Mb}(\mathrm{Y})-177$ & $\mathrm{Dm}(\mathrm{I})-337$ & $\operatorname{Dm}(Y)-259$ \\
\hline Minimum HBL & $M p(I)-69$ & $M p(Y)-73$ & $M p(I)-65$ \\
\hline
\end{tabular}

points out an unbiased recovery of species richness and rank abundance order by I and Y pitfall designs, indicating that studies that differ only in this matter are comparable.

Differences in pitfall size (35, 62, and 100 L buckets) did not lead to a different perception of species richness, relative abundance and community structure of leaf litter amphibian and lizard species. This is in agreement with RibeIro-JúNIOR et al. (2008) who only compared buckets of 35 and 62 L. Therefore, it seems that buckets of $35 \mathrm{~L}$ are adequate enough for sampling these animals. Even considering the largest species within these groups, no significant differences were observed, except between buckets of 62 and $100 \mathrm{~L}$ for amphibians. However, as no differences in size of captured amphibians were found between 35 and $62 \mathrm{~L}$ buckets, and 35 and $100 \mathrm{~L}$ buckets, the difference observed between 62 and $100 \mathrm{~L}$ buckets cannot be attributable to size. Our results contradict Cechin \& Martins (2000) who suggested the use of large pitfalls $(100 \mathrm{~L})$ to obtain more species and larger reptiles. Other studies (Friend et al. 1989, THOMPSON et al. 2005) also found differences, but these authors compared PVC pipes and buckets, where the form of the container also played a role.

For small mammals, however, number of species was higher in $100 \mathrm{~L}$ buckets than in the smaller ones. Thomson et al. (2005) found that $600 \mathrm{~mm}$ deep pipes registered more small mammal species than 20 L buckets, and they suggested that the largest trappable species could be jumping out of the buckets. How et al. (1984) also pointed out that some species of small mammals are able to jump or climb out of pitfall traps. Present data suggest that buckets of $100 \mathrm{~L}$ prevent escaping more efficiently than those of 35 and $62 \mathrm{~L}$. However, no difference in size of the animals caught by the three different bucket sizes was found, in spite of the fact that it could be expected that larger animals would have more chance of jumping out of the bucket.

There were a few cases where species were absent from one of the pitfall trap types but, except for P. ephippifer, samples were smaller than 10 specimens per species and absence may result from chance alone. Even in the case of P. ephippifer we cannot discard the effect of other variable(s) than bucket size. On the other hand, at least some amphibians, as well as some lizards, are able to climb out of buckets (TCSAP pers. obs.) and differences in size and/or format of the buckets may facilitate or hinder their escape. However, our results indicate that even if such differences exist, they were not enough to produce statistically significant differences in the analysed parameters.

Even though snake data were not statistically analyzed, our preliminary observations suggest that pitfalls, even of 100 $\mathrm{L}$, are not effective for sampling this group, as already observed by MASCHIO et al. (2009) for the same study area. A total effort of 1,206 trap nights were necessary to record 10 species (12 individuals), while by only walking to verify the pitfalls (about four hours per day) we could record 14 species (21 individuals). CECHIN $\&$ Martins (2000) and Bernarde (2008) recommended the use of $100 \mathrm{~L}$ pitfalls as an extremely efficient technique to sample snake community in Brazil. Our data do not corroborate this observa- 
tion. The technique however is useful as a complementary sampling method, especially regarding smaller, (semi-) fossorial snakes that are difficult to sample by active collecting.

For a number of ecological studies that includes the vertebrate leaf litter fauna it is important to understand the effectiveness and biases of different sampling methods (e.g. Umetsu et al. 2006, Maritz et al. 2007, Ribeiro-Júnior et al. 2008). Here, it is shown that studies of species richness, relative abundance and community structure of leaf litter amphibians and lizards are not significantly affected by different pitfall trap designs and sizes, at least within certain limits. However, the same was not true for small mammals, for which larger pitfall traps showed a higher species richness. As a result, the use of larger pitfall traps $(100 \mathrm{~L})$ to sample the terrestrial vertebrate fauna in multidisciplinary studies is recommented, maximizing the results obtained. On the other hand, if the study is restricted to the herpetofauna, 35L buckets, which are cheaper and easier to install, may be used. According to JAMEs et al. (1999) and SHerL (2001) the limited financial resources available for conservation must be allocated with care, including the choice of sampling methods for the study of biodiversity that are most cost-effective (e.g. Gardner et al. 2007, Gardner et al. 2008). We hope the present study will be useful to guide Neotropical forest herpetologists and mammalogists to improve the effectiveness of their sampling methods.

\section{ACKNOWLEDGMENTS}

We thank Danilo L. Arcoverde and Stephenson H.F. Abrantes for assistance in the field, and Marinus S. Hoogmoed for his help with amphibian identification. The project was funded by Amazonia Biodiversity Research Program/PPBioAmazônia, of the Brazilian Ministry of Science and Techonology and coordinated by Museu Paraense Emilio Goeldi. MMA/ IBAMA gave permission to work in the Floresta Nacional de Caxiuanã. We thank D. Astua and two anonymous reviewers for helping to improve an earlier version of the manuscript.

\section{LITERATURE CITED}

Almeida, S.S.; P.L.B. Lisboa \& A.S.L. Silva. 1993. Diversidade Florística de uma comunidade arbórea na Estação Científica Ferreira Penna, em Caxiuanã (Pará). Boletim do Museu Paraense Emílio Goeldi, série Botânica 9: 99-120.

Amaral, D.D.; S.S. Almeida \& D.C.T. Costa. 2009. Contribuições ao manejo florestal de espécies de valor madeireiro e não madeireiro na Floresta Nacional de Caxiuanã, p. 199-228. In: P.L.B. LisBoA (Ed.). Caxiuanã. Desafios para a conservação de uma Floresta Nacional na Amazônia. Belém, Museu Paraense Emílio Goeldi.

Ávila-Pires, T.C.S. \& M.S. Hoogmoed. 1997. The herpetofauna, p. 389-401. In: P.L.B. LisBoA (Ed.). Caxiuanã. Desafios para a conservação de uma Floresta Nacional na Amazônia.
Belém, Museu Paraense Emílio Goeldi.

Bernarde, P.S. 2008. Ecologia e métodos de amostragem de répteis squamata, p. 189-201. In: S.P.C. Silva; D.A.P. Gomes-SiLVA; J.S. Melo \& V.M.L. Nascimento (Eds). Coletânea de textos: Manejo e monitoramento da fauna silvestre em florestas tropicais. Rio Branco, VIII Congresso Internacional sobre Manejo de Fauna Silvestre na Amazônia e América Latina.

Bernardi, J.A.R.; R.A. Estupiñán \& Galatti, U. 1999. New anuran records from the Floresta Nacional de Caxiuanã, eastern Amazon, Brazil. Herpetological Review 30: 176-177.

Bratthwatte, R.W. 1983. A comparison of two pitfall trap systems. Victorian Naturalist 100: 163-166.

Bury, R.B. \& P.S. Corn. 1987. Evaluation of pitfall trapping in northwestern forests: trap array with drift fences. Journal of Wildlife Management 51: 112-119.

Bury, R.B. \& M.G. RaphaEL. 1983. Inventory methods for amphibians and reptiles, p. 416-419. In: J.F. Bell \& T. Atterburry (Eds). Renewable Resource Inventories for Monitoring Changes and Trends. Corvallis, Oregon State University.

Cechin, S.Z. \& M. Martins. 2000. Eficiência de armadilhas de queda (pitfall traps) em amostragens de anfíbios e répteis no Brasil. Revista Brasileira de Zoologia 17 (3): 729-740. doi: 10.1590/S0101-81752000000300017.

Clarke, K.R. \& R.M. Warwick. 2001. Change in marine communities: an approach to statistical analysis and interpretation. Plymouth, Plymouth Marine Laboratory.

ColWELL, R.K. 2004. Statistical estimation of species richness and shared species from samples. Available online at: http:/ /purl.oclc.org/estimates [Accessed: 07.24.2007]

Costa, A.C.L.; S.S. Almeida; C.R. Carvalho; P. Meir; Y.M. Malhi; R.F. Costa; J.A. Silva Jr; M.C. Costa; B.T. Tanaka; R.A. Fisher; E.D. Sotta; L.L. Oliveira; P.H.L. Gonçalves; A.P. Braga \& P.N. BARRETO. 2009. Experimento Esecaflor-LBA em Caxiuanã, p. 45-90. In: P.L.B. LisboA (Ed.). Caxiuanã. Desafios para a conservação de uma Floresta Nacional na Amazônia. Belém, Museu Paraense Emílio Goeldi.

ENGE, K.M. 2001. The pitfalls of pitfall traps. Journal of Herpetology 35: 467-478.

EstupiÑÁN-T, R.A.; J.A.R. BERNARdi \& U. GalatTi. 2002. Fauna anura, p. 541-553. In: P.L.B. LisBoA (Ed.). Caxiuanã: populações tradicionais, meio físico e diversidade biológica. Belém, Museu Paraense Emílio Goeldi.

Friend, G.R. \& D.S. Mitchell. 1988. Efficient pitfall trap designs for surveying small vertebrates. Landnote 1/88: 1-4.

Friend, G.R.; G.T. Smith; D.S. Mitchell \& C.R. Dickman. 1989. Influence of pitfall and drift fence design on capture rates of small vertebrates in semi-arid habitats of western Australia. Australian Wildlife Research 16: 1-10.

Gardner, T.A.; J. Barlow; L.T.W. Parry \& C.A. Peres. 2007. Predicting the uncertain future of tropical forest species in a data vacuum. Biotropica 39: 25-30. doi: 10.1111/j.17447429.2006.00228.x. 
Gardner, T.A.; J. Barlow; I.S. Araujo; T.C.S. Ávila-Pires; A.B. Bonaldo; J.E. Costa; M.C. Espósito; L.V. Ferreira; J. Hawes; M.I. Hernandez; M. Hoogmoed; R.N. Leite; N.F. Lo-Man-Hung; J.R. Malcolm; M.B. Martins; L.A.M. Mestre; R. Miranda-Santos; A. Nunes-Gutjahr; W.L. Overal; L.T.W. Parry; S.L. Peters; M.A. Ribeiro-Júnior; M.N.F. Silva; C. Silva-Motta \& C. Peres. 2008. The cost-effectiveness of biodiversity surveys in tropical forests. Ecology Letters 11: 139-150. doi: 10.1111/j.14610248.2007.01133.x.

Gotelli, N.J. \& R.K. Colwell. 2001. Quantifying biodiversity: procedures and pitfalls in the measurement and comparison of species richness. Ecology Letters 4: 379-391. doi: 10.1046/ j.1461-0248.2001.00230.x.

Greenberg, C.H.; D. Neary \& L.D. Harris. 1994. A comparison of herpetofaunal sampling effectiveness of pitfall, single-ended, and double-ended funnel traps used with drift fences. Journal of Herpetology 28: 319-324.

Hobbs, T.J.; S.R. Morton; P. Masters \& K.R. Jones. 1994. Influence of pit-trap design on sampling reptiles in arid spinifex grasslands. Wildlife Research 21: 483-490.

HOPPER, S.D. 1981. A pit trap survey of small mammals, lizards and frogs on Two Peoples Bay Nature Reserve. Perth, Department of Fisheries and Wildlife, Western Australia, Report 43.

How, R.A.; W.F. Humphreys \& J. Dell. 1984. Vertebrate surveys in semi-arid Western Australia, p. 193-216. In: K. Myers \& C.R. MARGUles (Eds). Survey method for nature conservation. Proceedings of a workshop held at Adelaide University, 31 August - 2 September 1983. Camberra, CSIRO Water and Land Resources.

James, A.N.; K.J. Gaston \& A. Balmford. 1999. Balancing the Earth's accounts. Nature 401: 323-324.

LamberT, T.D.; J.R. Malcolm \& B.L. Zimmerman. 2005. Variation in small mammal species richness by trap height and trap type in Southeastern Amazonia. Journal of Mammalogy 86: 982990. doi: 10.1644/1545-1542(2005)86[982:VISMSR]2.0.CO;2.

MagurRan, A.E. 2004. Measuring Biological Diversity. Oxford, Blackwell Science.

Maritz, B.; G. Masterson; D. Mackay \& G. Alexander. 2007. The effect of funnel trap type and size of pitfall trap on trap success: implications for ecological field studies. AmphibiaReptilia 28: 321-328. doi: 10.1163/156853807781374746.

Maschio, G.F.; M.C. Santos-Costa \& A.L.C. Prudente. 2009. Comunidade de serpentes da região de Caxiuanã com avaliação da eficiência dos métodos de captura, p. 589-603. In: P.L.B. LisboA (Ed.). Caxiuanã. Desafios para a conservação de uma Floresta Nacional na Amazônia. Belém, Museu Paraense Emílio Goeldi.

McCune, B. \& J.B. Grace. 2002. Analysis of ecological communities. Gleneden Beach, MJM Software Designs.

MengaK, M. \& D.C.J. GuYnn. 1978. Pitfalls and snap traps for sampling small mammals and herpetofauna. American Midland Naturalist 118: 284-288.
Menkhorst, P.W. 1982. Pitfall trapping of reptiles in the Big Desert, Victoria. Victorian Naturalist 99: 66-70.

Morton, S.R.; M.W. Gillam; K.R. Jones \& M.R. Fleming. 1988. Relative efficiency of different pit-trapping systems for sampling reptiles in spinifex grassland. Austral. Wildlife Research 15: 571-577.

Moseby, K. \& J.L. Read. 2001. Factors affecting pitfall capture rates of small ground vertebrates in arid South Australia. II. Optimum pitfall trapping effort. Wildlife Research 28: 61-71.

Ribeiro-Júnior, M.A.; T.A. Gardner \& T.C.S. Ávila-Pires. 2008. Evaluating the effectiveness of herpetofaunal sampling techniques across a gradient of habitat change in a tropical forest landscape. Journal of Herpetology 42: 733-749. doi: 10.1670/07-097R3.1.

Rice, C.G.; E.E. Jorgensen \& S. Demarais. 1994. A comparison of herpetofauna detection and capture techniques in southern New México. Texas Journal of Agriculture and Natural Resources 7: 107-114.

Rolfe, J.K. \& N.L. McKenzie. 2000. Comparison of methods used to capture herpetofauna: an example from the Carnavon Basin. Records of the Western Australian Museum 61 (Suppl.): 361-370.

Ryan, T.J.; T. Philippi; Y.A. Leiden; M.E. Dorcas; T.B. Wigley \& J.W. GibBons. 2002. Monitoring herpetofauna in a managed forest landscape: effects of habitat types and census techniques. Forest Ecology and Management 167: 83-90. doi: 10.1016/ S0378-1127(01)00692-2.

Santos-Filho, M.; D.J. Silva \& T.M. Sanaiotti. 2006. Efficiency of four trap types in sampling small mammals in Forest fragments, Mato Grosso, Brazil. Mastozoologia Neotropical 13: 217-225. ISSN 1666-0536.

SHEIL, D. 2001. Conservation and biodiversity monitoring in the tropics: realities, priorities, and distractions. Conservation Biology 15: 1179-1182. doi: 10.1046/j.1523-1739.2001. 0150041179.x.

SPSS. 2001. Statistical Package for the Social Sciences v.11.5. Chicago.

Thompson, G.G.; P.C. Withers; E.R. Pianka \& S.A. Thompson. 2003. Assessing biodiversity with species accumulation curves; inventories of small reptiles by pit-trapping in Western Australia. Austral Ecology 28: 361-383. doi: 10.1111/j.14429993.2003.tb00261.x.

Thompson, S.A.; G.G. Thompson \& P.C. Withers. 2005. Influence of pit-trap type on the interpretation on fauna diversity. Wildlife Research 32: 131-137. doi:10.1071/WR03117.

Umetsu, F.; L. Naxara \& R. Pardini. 2006. Evaluating the efficiency of pitfall traps for sampling small mammals in the Neotropics. Journal of Mammalogy 87: 757-765. doi: 10.1644/05-MAMM-A-285R2.1.

Submitted: 18.VI.2010; Accepted: 15.XI.2010. Editorial responsibility: Diego A. de Moraes 